УДК 796.035:613.99

\title{
ВПЛИВ ЗАНЯТЬ СУСLЕ НА ФІЗИЧНИЙ СТАН ЖІНОК МОЛОДОГО ВІКУ
}

\author{
Свгеній Стрикаленко ${ }^{1}$, Олег Шалар ${ }^{1}$, Регіна Андрсєва ${ }^{1}$, Ігор Жосан ${ }^{1}$, \\ Вікторія Коваль ${ }^{1}$, Оксана Швець ${ }^{2}$ \\ ${ }^{1}$ Херсонський державний університет, Херсон, Україна, r.andreeva1306@gmail.com \\ ${ }^{2}$ Вінницький державний педагогічний університет імені Михайла Коцюбинського, Вінниця, Україна, \\ o.shvets1802@gmail.com
}

https://doi.org/10.29038/2220-7481-2019-04-68-73

\begin{abstract}
Анотації
Актуальність теми дослідження. Сусlе є аеробним видом спорту, оскільки сприяє зміцненню серцевосудинної системи, розвитку м'язової системи, підвищує рівень загальної та спеціальної витривалості й дає змогу корегувати вагові показники. Незважаючи на вдосконалення сучасних фітнес-технологій i велику кількість розроблених фітнес-програм, більшість із них не засновані на глибокому розумінні функціональних механізмів тренування жінок репродуктивного вікового періоду й не враховують проблем індивідуалізації задля оптимізації іï ефективності. Мета й методи дослідження. Мета роботи полягає в розробці методики занять Cусlе та визначенні ефективності їх впливу на показники фізичного стану жінок молодого віку. Контингент дослідження становили жінки молодого віку, які займались у Херсонському фітнес-клубі «Наmmer». Застосовано такі методи дослідження, як методи педагогічного тестування для оцінки рівня фізичної підготовленості, медико-біологічні методи для оцінки функціонального стану серцево-судинної й дихальної систем; педагогічний експеримент, спрямований на впровадження методики використання тренувальних занять Сусlе для покращення показників функціональної та фізичної підготовленості жінок молодого віку, методи математичної статистики. Результати роботи та ключові висновки. За рахунок використання занять Сусlе за всіма тестами відбулися позитивні зрушення від 11,3 до 39,6 \%. Установлено, що розходження між вихідними й кінцевими результатами за чотирма досліджуваними тестовими завданнями виявилися достовірними (два - із фізичної підготовленості - рівномірний біг на 2000 м, згинання та розгинання рук в упорі лежачи, і два - із функціонального стану - Індекс проби Руф'є, Індекс гарвардського степ-тесту) $(\mathrm{p}<0,05, \mathrm{p}<0,01)$. Це підтверджує думку про цілеспрямований вплив фітнес-тренувань із застосуванням спеціалізованого обладнання Сусlе на механізми функціональної адаптації до тривалих фізичних навантажень.

Ключові слова: фітнес, Cусlе, жінки молодого віку, фізична та функціональна підготовленість.
\end{abstract}

Евгений Стрикаленко, Олег Шалар, Регина Андреева, Игорь Жосан, Виктория Коваль, Оксана Швец. Влияние занятий Сусlе на физическое состояние женщин молодого возраста. Актуальность темы исследования. Сусlе является аэробным видом спорта, поскольку способствует укреплению сердечнососудистой системы, развитию мышечной системы, повышает уровень общей и специальной выносливости и позволяет корректировать показатели массы тела. Несмотря на усовершенствование современных фитнестехнологий и значительное количество разработанных фитнес-программ, большинство из них не основаны на глубоком понимании функциональных механизмов тренировки женщин репродуктивного возраста, и не учитывают проблемы индивидуализации с целью оптимизации их эффективности. Цель и методы исследования. Цель работы состоит в разработке методики занятий Сусlе и определении эффективности их влияния на показатели физического состояния женщин молодого возраста. Контингент исследования представляли женщины молодого возраста, которые занимались в Херсонском фитнес-клубе «Наттег». Использовались такие методы исследования: методы педагогического тестирования для оценки уровня физической подготовленности; медико-биологические методы для оценки функционального состояния сердечно-сосудистой и дыхательной систем; педагогический эксперимент, направленный на внедрение методики использования тренировочных занятий Сусlе для улучшения показателей функциональной и физической подготовленности женщин молодого возраста; методы математической статистики. Результаты работы и ключевые выводы. За счет использования занятий Сусlе по всем тестам произошли позитивные изменения от 11,3 до $39,6 \%$. Установлено, что расхождения между исходными и конечными результатами по четырем исследуемым тестовым заданиям оказались достоверными (два - по физической подготовленности - равномерный бег на 2000 м, сгибание и разгибание рук в упоре лежа, и два - по функціональному состоянию - Индекс пробы Руфье, Индекс гарвардского степ-теста) ( $<<0,05, \mathrm{p}<0,01)$. Это подтверждает мнение о целенаправленном влиянии фитнес-тренировок с использованием специализированного оборудования Сусlе на механизмы функциональной адаптации к длительным физическим нагрузкам.

Ключевые слова: фитнес, Cусlе, женщины молодого возраста, физическая и функциональная подготовленность. 
Yevhenii Strykalenko, Oleh Shalar, Rehina Andrieieva, Ihor Zhosan, Viktoriia Koval, Oksana Shvets. The Effect of Cycle Training on the Physical Condition of Young Women. Relevance of the Research Topic. Cycle is an aerobic kind of sport, as it influences the strengthening of cardiovascular system, muscles development, increases the level of general and special endurance and enables to correct weight parameters. Despite the advancement of modern fitness technologies and the large number of fitness programs developed, most of them are not based on a deep understanding of the functional mechanisms of training women in reproductive age, and do not take into account the problems of individualization in order to optimize its effectiveness. The Purpose and Research Methods. The purpose of the paper is to devise the methods of Cycle training lessons and reveal the efficiency of their influence on the rate of the physical sate of young women. The contingent of the research is young women, who did sports in the gym "Hammer". In the research we have implemented such methods: methods of pedagogical testing of physical training, medical-biological methods of the evaluation of functional condition of cardiovascular and respiratory system, pedagogical experiment, focused on implementing the methods of Cycle training to increase the rate of functional and physical training level of young women, methods of mathematic statistics. The Research Results and Conclusions. Cycle training lessons demonstrate positive results of test's rate level from 11,3 to $39,6 \%$. It has been revealed that discrepancy between initial and final data of all the four test parameters are valid (two of them refer to physical training - even for $2000 \mathrm{~m}$. running, arm bending and extension in the upper arm support position, two parameters refer to functional physical training - the Ruffier functional test, the index of Harvard's step-test) $(\mathrm{p}<0,05, \mathrm{p}<0,01)$. It proves the statement about the direct influence of Cycle fitness-trainings on the mechanisms of functional adaptation to long physical activity.

Key words: fitness, Cycle, young women, physical and functional training.

Вступ. Фітнес - один із найбільш ефективних тренувальних засобів різнобічного розвитку організму людини. Значна кількість різновидів фітнесу дає змогу диференційовано та максимально ефективно дозувати фізичні навантаження, що робить його використання доступним для людей різних вікових груп $[3,4]$.

Науковці [1; 4; 7] дослідили, що перший зрілий вік характеризується високими показниками фізичної підготовленості та працездатності, оптимальною адаптацією до несприятливих факторів зовнішнього середовища, низькими показники захворюваності та високими показниками репродуктивності.

Використання різноманітних фізичних вправ дає змогу відновити й підвищити рівень фізичної підготовленості та працездатності. Людина з високими показниками фізичної підготовленості при помірній фізичній активності сповільнює процеси старіння на 10-20 років [2; 5; 6; 7; 11]. Відповідно заняття фітнесом є найбільш доступним і корисним видом рухової діяльності для жінок молодого віку.

Одним із перспективних напрямів фітнесу є Cусlе, що зародився в Америці. Його засновником став американський велосипедист Джон Голдберг, який був великим шанувальником фітнесу. На початку 90-х років він розробив стаціонарний велосипед полегшеної конструкції для гонок у закритих приміщеннях і власний стиль велотренувань, які імітували захопливі велогонки. Цей напрям дуже швидко став популярним в Америці, а дещо пізніше - і в Свропі, отримавши назву «сайклінг» [9; 11].

Нині існує безліч різновидів фітнесу, які дають змогу впливати на різні складники підготовленості жінок молодого віку. Сусlе є одним із різновидів високоінтенсивних кардіотренувань, який відрізняється від інших видів фітнесу своєю емоційністю, інтенсивністю та застосуванням спеціального обладнання - спін-байку [9; 10; 14; 15]. При складанні тренувально-оздоровчих програм важливо враховувати індивідуальні можливості організму жінок та їхнє бажання виконувати запропоновану роботу [12; 13].

Все вищевикладене об'єктивно доводить актуальність і необхідність дослідження впливу занять Cусlе на показники фізичної та функціональної підготовленості жінок молодого віку.

Мета дослідження полягає в розробці методики занять Сусlе й визначенні ефективності їх впливу на показники фізичного стану жінок молодого віку.

Матеріал і методи дослідження. Дослідження тривало впродовж 2017-2018 рр., упровадження експериментальної методики відбувалося протягом одного року. Тренування в групі проходило тричі на тиждень.

Контингент дослідження становили жінки молодого віку, які займалися в Херсонському фітнесклубі «Наmmer» під керівництвом тренера Максима П. Кількість жінок - учасників дослідження становила 15 осіб віком від 27 до 38 років. Матеріально-технічна база, обладнання та інвентар для всіх учасниць був однаковим. Під час проведення експериментальної роботи від всіх учасниць отримано інформовану згоду на участь у дослідженні.

На першому етапі за допомогою комплексу спеціальних тестів досліджено рівень фізичної й функціональної підготовленості жінок молодого віку експериментальної групи. Наступним кроком експериментальної роботи стало впровадження експериментальної методики з використанням трену- 
вань Сусlе. Завершальний етап експериментально-дослідної роботи передбачав проведення повторного тестування й використання методів математичної статистики задля визначення ефективності впровадження занять Сусlе у тренувальний процес жінок молодого віку.

Відповідно до мети дослідження визначено такі методи:

- педагогічне тестування фізичної підготовленості (швидкісно-силових якостей - стрибок у довжину з місця; силових якостей - згинання та розгинання рук в упорі лежачи, піднімання тулуба в сід; гнучкості - нахил тулуба вперед із положення сидячи; витривалості - рівномірний біг на 2000 м);

- медико-біологічні методи оцінки функціональної підготовленості жінок молодого віку (проба Штанге, проба Генчі, індекс Руф'є, індекс Гарвардського степ-тесту);

- педагогічний експеримент із метою доведення ефективності запропонованої методики проведення тренувальних занять Сусlе для покращення показників фізичної та функціональної підготовленості жінок молодого віку;

- методи математичної статистики.

Для обробки отриманих результатів дослідження застосовано розрахунок середнього арифметичного значення й помилку середнього арифметичного, відсоткові значення. Достовірність розбіжностей між показниками досліджуваних експериментальної групи, а також достовірність приросту результатів визначали за t-критерієм Стьюдента при $\mathrm{p}<0,05, \mathrm{p}<0,01, \mathrm{p}<0,001$.

Тренування жінок молодого віку за методикою Сусlе проводили на спеціальному велотренажері, який називався «Сайкл». Сайкл-тренажер, або спін-байк, являє собою стаціонарний полегшений велотренажер, який призначений для гонок у закритих приміщеннях. Заняття на тренажері максимально імітують їзду на велосипеді.

Починати змінювати навантаження можемо за допомогою трьох елементів: рівня опору педалей, швидкості обертальних рухів, зміни положення корпусу. Інструктор задає загальний настрій і ритм заняття, уважно стежить за діями кожного учасника тренування, індивідуально регулюючи навантаження. Темп і швидкість виконання вправ змінюються кожні 5-6 хвилин, залежно від обраної програми. Перед початком тренування інструктор проводить коротку, інтенсивну розминку з метою підведення організму жінки до оптимального, для виконання тренувальної роботи, стану.

Сусlе-тренування відрізняється високим рівнем емоційності, різноманітності й зацікавленості, що дає змогу уникнути монотонності тренування. Практично всі заняття на сайкл-тренажерах проходять масово. Під час них усі учасники групи «змагаються» між собою. Залежно від матеріально-технічного забезпечення тренажерної зали, результати тренувальної роботи представляються на екран у вигляді індивідуальної динаміки руху, кількості витрачених калорій, збільшення або зменшення темпу виконання вправ. Їзда на імітованому велосипеді завжди проходить під музичний супровід із постійним консультуванням інструктора-тренера. Використання аудіосупроводу дає змогу не лише підвищити позитивну атмосферу в залі, але й реалізує практичну спрямованість полегшеного подолання значних фізичних навантажень.

Професійний супровід Сусlе аеробіки дає змогу збільшити іiі ефективність, порівняно з індивідуальними тренуваннями на спін-байках у домашніх умовах. Тренер-інструктор корегує кількість $\mathrm{i}$ потужність обертів сайклу, зміну пози, положення тулуба та рук.

Порівняно з іншими видами фітнесу, заняття Сусlе відрізняються значною кількістю переваг: запропоновані заняття дають змогу підвищити рівень розвитку загальної та спеціальної витривалості; у роботі одночасно задіяні практично всі м'язові групи, що дає змогу збільшити їх пружність і рельєфність; такі заняття дають змогу зробити кардіонавантаження більш природним; на відміну від бігу, зменшити навантаження на хребетний стовп; дати можливість для занять руховою активністю особам різних вікових груп.

Усі заняття з використанням сайкл-тренажера будувалися за певним алгоритмом. У підготовчій частині заняття застосовували ритмічну ходьбу або біг на тренажерах, що сприяють уключенню всіх м'язів у роботу. Основною метою цієї частини заняття є підготовка організму до виконання навантажень основної частини тренування.

Тривалість основної частини тренувального заняття Сусlе коливається в межах 50-60 хвилин із різними навантаженнями й темпами. Заняття проходять динамічно та вимагають високих енергетичних витрат. У середньому під час тренування на спін-байці долається відстань до 15-20 кілометрів. Крім того, умови виконання вправ і навантаження постійно варіюються. Вправи на спін-байці мають величезний спектр варіацій, перший із яких представлений звичайним обертання педалей із фіксацією рук на поручнях тренажера. Більш складним варіантом $є$ їзда стоячи, під час якої відбувається перерозподіл навантаження на інші м’язові групи. 
Швидкість руху на тренажері переважно становить 5-20 км/год. По завершенню роботи на Сусlетренажері використовуються спеціальні вправи, спрямовані на розслаблення й розтягнення м'язових груп.

Результати дослідження. Відповідно до поставлених завдань дослідження в ході проведення експериментальної частини роботи ми дослідили вихідні та кінцеві дані фізичної й функціональної підготовленості жінок молодого віку, котрі займаються у групах Cycle, порівняльний аналіз яких представлено в табл. 1.

Табличя 1

Достовірність розходжень між показниками фізичної та функціональної підготовленості жінок молодого віку протягом експерименту

\begin{tabular}{|c|c|c|c|c|}
\hline \multirow[t]{2}{*}{ Тестові випробування } & \multirow{2}{*}{$\begin{array}{c}\text { Вихідні дані } \\
\mathbf{X} \pm \mathbf{s}\end{array}$} & \multirow{2}{*}{$\begin{array}{c}\text { Кінцеві дані } \\
\mathbf{X} \pm \mathbf{s}\end{array}$} & \multicolumn{2}{|c|}{$\begin{array}{c}\text { Ступінь } \\
\text { достовірності }\end{array}$} \\
\hline & & & $\mathbf{t}$ & $\mathbf{p}$ \\
\hline \multicolumn{5}{|c|}{ Фізична підготовленість } \\
\hline Рівномірний біг, 2000 м, $c$ & $772,2 \pm 70,704$ & $652,4 \pm 49,101$ & 2,861 & $\mathrm{p}<0,05$ \\
\hline Стрибок у довжину з місця, $M$ & $1,68 \pm 0,109$ & $1,87 \pm 0,129$ & 1,844 & $p>0,05$ \\
\hline $\begin{array}{l}\text { Згинання та розгинання рук } \\
\text { в упорі лежачи, разів }\end{array}$ & $19,26 \pm 4,712$ & $26,9 \pm 6,146$ & 2,576 & $\mathrm{p}<0,05$ \\
\hline Піднімання тулуба в сід, разів & $29,6 \pm 6,706$ & $39,1 \pm 7,019$ & 1,913 & $p>0,05$ \\
\hline $\begin{array}{l}\text { Нахил тулуба вперед } \\
\text { із положення сидячи, } c M\end{array}$ & $9,1 \pm 4,389$ & $12,06 \pm 3,972$ & 0,762 & $\mathrm{p}>0,05$ \\
\hline \multicolumn{5}{|c|}{ Функціональна підготовленість } \\
\hline Проба Штанге, $c$ & $42,8 \pm 7,692$ & $49,86 \pm 7,501$ & 1,561 & $p>0,05$ \\
\hline Проба Генчі, $c$ & $24,6 \pm 4,548$ & $27,66 \pm 4,546$ & 0,811 & $\mathrm{p}>0,05$ \\
\hline Індекс проби Руф'є & $6 \pm 1,479$ & $5,25 \pm 1,484$ & 2,829 & $\mathrm{p}<0,05$ \\
\hline Індекс гарвардського степ-тесту & $59,13 \pm 8,627$ & $77,69 \pm 5,74$ & 3,015 & $\mathrm{p}<0,01$ \\
\hline
\end{tabular}

Порівнюючи результати фізичної підготовленості, ми виявили, що протягом педагогічного експерименту досліджувані показники жінок молодого віку зазнали суттєвих змін. Проте достовірні розходження встановлені лише під час виконання тестових завдань, що дають змогу визначити рівень загальної витривалості $(\mathrm{t}=2,861$ при $\mathrm{p}<0,05)$ та рівень розвитку сили верхнього плечового пояса $(\mathrm{t}=2,576$ при $\mathrm{p}<0,05)$. На нашу думку, це пов'язано з тим, що під час використання фітнес-тренувань Cycle значного розвитку зазнають саме ті фізичні якості, які безпосередньо сприяють виконанню тривалих фізичних навантажень. Стосовно достовірності розходжень між показниками сили верхнього плечового пояса зазначимо, що використання спеціальних вправ на руки 3 додатковими обтяженнями в ході Сусlе-тренувань $є$ міцною передумовою розвитку досліджуваних показників, що підтверджено отриманими експериментальними даними.

Недостовірність розходжень між показниками в тестах «стрибок у довжину з місця», «піднімання тулуба в сід» та «нахил тулуба вперед у положенні сидячи» пов'язана з тим, що фізичні якості, які визначаються за допомогою даних тестів, мають менший рівень залучення до роботи під час тренувань Cусlе або можуть бути покращені під час виконання інших фізичних вправ.

Аналіз усереднених результатів тестових вправ, що визначають рівень розвитку функціональної підготовленості, дав змогу встановити, що протягом експериментальної роботи за індексами проби Руф'є й гарвардського степ-тесту відбулися достовірні зміни досліджуваних показників (t=2,829 при $\mathrm{p}<0,05$ та $\mathrm{t}=3,015$ при $\mathrm{p}<0,01$ відповідно). На нашу думку, це підтверджує думку про цілеспрямований вплив фітнес-тренувань Cусlе на механізми функціональної адаптації до тривалих фізичних навантажень. Потрібно зазначити, що розходження між усередненими результатами проб Штанге та Генчі, незважаючи на значні абсолютні й відносні прирости, виявилися недостовірними $(\mathrm{p}>0,05)$.

Дискусія. Максимальний прояв сили в жінок, як і перші ознаки ії зниження, спостерігаємо вже в першому періоді зрілого віку (23-25 років), однак різке ії зниження зареєстровано після 50 років (Круцевич, 2003). За результатами нашого дослідження, силові якості жінок покращилися на 39,6 \%, а абсолютний приріст становив 7,6 раза за тестом «згинання та розгинання рук в упорі лежачи». Також за тестом піднімання тулуба в сід абсолютний приріст дорівнював 9,5 раза, що вказує на покращення сили черевного преса на 32,1 \%. Отримані результати в цілому підтверджують думку дослідників, оскільки виявлені прирости $є$ недостовірними. 
Прояв швидкості погіршується в період 22-50 років, координованість рухів знижується в 30 50 років, а гнучкість має тенденцію до спаду в жінок після 25 років. Причини порушення фізичних можливостей зумовлені внутрішніми й зовнішніми факторами (Богдановська, 2013). У нашому дослідженні зміни в показниках гнучкості жінок довели доцільність регулювання зовнішніх факторів впливу через упровадження спеціалізованих засобів, а саме в показниках тесту «нахил тулуба вперед із положення сидячи», абсолютний приріст становив 2,96 сантиметра (покращення - на 32,5\%).

На думку деяких фахівців, погіршення витривалості жінок пов'язано 3 порушенням функції киснево-транспортної системи, падіння швидкості - зі зниженням м'язової сили, функцій енергозабезпечення, порушенням координації в центральній нервовій системі (Борилкевич, 2006). За результатами нашого дослідження, рівень загальної витривалості жінок за тестом «біг на 2000 метрів» покращився на $15,5 \%$. В абсолютних показниках результат підвищився на 119,8 секунди, що підтверджує ефективність впливу Сусlе-тренувань на стимулювання функцій енергозабезпечення в ході раціональної організованих видів рухової активності.

Із віком порушуються регуляція й ритм дихання, однак науковці доводять, що під впливом фізичних навантажень дихання та газообмін значно покращуються (Хоули, 2004). У нашому дослідженні виявлено стійкість дихальної системи жінок до гіпоксії за показниками функціональної проби Штанге. Абсолютний приріст за цією пробою становив 7,06 секунди, що дорівнював 16,5 \%. Експериментально встановлено, що під впливом систематичних занять Сусlе ритм дихальних рухів у жінок став більш рівномірним, покращилася глибина дихання. Тобто відбулась адаптація дихальної системи жінок до фізичних навантажень.

В. Ареф'єв вважає, що приріст маси тіла до 25 років у жінок пов'язаний із недостатньою руховою активністю. За період із 18 до 25 років приріст маси тіла становить $10 \%$, що супроводжується збільшенням абсолютної сили на $10 \%$. Кожен віковий період характеризується визначеними змінами в організмі. Першому періоду зрілого віку притаманні найвищі значення фізичної працездатності й підготовленості, оптимальна адаптація до несприятливих факторів зовнішнього середовища, найменші показники захворюваності (Ареф'єв, 2005). Однак, уже починаючи з 30 років, відбувається зниження низки показників фізичної працездатності та функціональної підготовленості. Як довели наші дослідження, найбільший абсолютний приріст показників фізичної працездатності відбувся за індексом гарвардського степ-тесту (18,6 одиниць), що вказує на покращення відновлювальних процесів в організмі жінок на 31,4 \%. За показниками проби Руф'є абсолютний приріст становив 0,75 одиниці, що дорівнює 14,3 \%. На нашу думку, установлена суперечність зумовлена ефективністю застосування різних форм рухової активності жінок молодого віку.

Отримані в ході дослідження результати вказують на той факт, що Сусlе-тренування позитивно впливає на показники фізичного стану жінок молодого віку, що експериментально доведено встановленими достовірними приростами.

Висновки. У сучасній системі фізичного виховання існує велика кількість різноманітних засобів і методів, що сприяють підвищенню рівня підготовленості різних груп населення. У ході експериментальної частини роботи доведено, що одним із перспективних напрямів підвищення рівня фізичної та функціональної підготовленості є використання Сусlе-тренажера. Зміст програми тренувань має високу варіацію навантажень і різнобічно впливає на всі сторони фізичної та функціональної підготовки.

Експериментально встановлено, що використання Cусle $\epsilon$ ефективним для підвищення рівня фізичної й функціональної підготовленості жінок молодого віку (відсоток приросту за різними тестами становив від 11,3 до 39,6 \%). За даними математико-статистичного аналізу зміни показників чотирьох тестів виявилися достовірними ( $\mathrm{p}<0,05, \mathrm{p}<0,01)$.

Перспективи подальших наукових досліджень із проблеми оптимізації фізичної та функціональної підготовленості жінок молодого віку полягають у дослідженні ефективності застосування інших інноваційних методик та розробці індивідуальних тренувальних програм для інших вікових груп із різним рівнем підготовленості.

\section{Джсерела та література}

1. Арефьев В. Г. Современные фитнес-технологии повышения уровня физического состояния женщин первого зрелого возраста. Физическое воспитание студентов творческих спеціальностей. 2005. № 1. C. $73-78$.

2. Богдановська Н. В. Вплив оздоровчої аеробіки на функціональний стан організму жінок 20-30 років. Вісник Запорізького національного університету. 2013. (10) 1. С. 89-93.

3. Борилкевич В. Е. Фитнесс - современное понятие в мировом оздоровительном движении. Термины и понятия в сфере физической культуры. 2006. 1. С. 33-35. 
4. Велла М. Анатомия фитнеса и силовых упражнений для женщин. Москва: Попурри, 2015. 969 с.

5. Калашников Д. Г. Теория и методика фитнес-тренировки: учеб. персонального тренера. Москва: Франтэра, 2003. 275 с.

6. Ким Н. Фитнес. Москва: Сов. спорт, 2006. 454 с.

7. Круцевич Т. Ю. Теорія і методика фізичного виховання: методика фізичного виховання різних груп населення. Київ: Олімп. літ., 2003. Т. 2. 391 с.

8. Кузнецов А. Анатомия фитнеса. Москва: Феникс, 2008. С. 224.

9. Невский А. П. Энциклопедия фитнеса и физической культуры. Москва: Зебра Е, 2011. Т. 2. 726 с.

10. Строган Д. О., Стрикаленко Є. А., Шалар О. Г. Фізична підготовка жінок засобами пружинячих черевиків «KANGOO JUMPS». Науковий часопис Національного педагогічного університету імені М. П. Драгоманова. 2017. (86) 17. С. 331-336.

11. Хоули Э. Т. Руководство инструктора оздоровительного фитнеса. Киев: Олимп. лит. 2004.362 с.

12. Шалар О. Г. Відповідальне ставлення до здоров'я як провідна цінність фізичного виховання. Теорія та методика фізичного виховання. 2009. (5). С. 26-31.

13. Шалар О. Г., Науменко М. В. Стрикаленко Е. А. Формирование мотивационно-ценностного отношения студентов к собственному здоровью. Физическое воспитание студентов. 2010. (5). С. 80-83.

14. Dr. Howie Wenger. Army Fitness Manual. Ontario: Command, 2005. 118 p.

15. Schlosberg S., Neporent L., Drenth T. S. Fitness For Dummies, 3rd Edition. Indiana: Wiley Publishing, 2005. $434 \mathrm{p}$.

\section{References}

1. Arefev, V. G. (2005). Sovremennye fitnes-tehnologii povysheniya urovnya fizicheskogo sostoyaniya zhenshin pervogo zrelogo vozrasta [Modern fitness technologies to increase the level of physical condition of women of the first adulthood]. Fizicheskoe vospitanie studentov tvorcheskih specialnostej - Physical education of students of creative specialties, (1), 73-78 [in Russian].

2. Bogdanovska, N. V. (2013). Vpliv ozdorovchoyi aerobiki na funkcionalnij stan organizmu zhinok 20-30 rokiv [The influence of health aerobics on the functional state of the body of 20-30 years old women]. Visnik Zaporizkogo nacionalnogo universitetu - Bulletin of Zaporizhzhya National University, (10) 1, 89-93 [in Ukrainian].

3. Borilkevich, V. E. (2006). Fitness - sovremennoe ponyatie v mirovom ozdorovitelnom dvizhenii [Fitness is a modern concept in the global wellness movement]. Terminy i ponyatiya $v$ sfere fizicheskoj kultury - Terms and concepts in the field of physical culture. 1, 33-35 [in Russian].

4. Vella, M. (2015). Anatomiya fitnesa i silovyh uprazhnenij dlya zhenshin [Anatomy of fitness and weight exercises for women]. Moskva: Popurri [in Russian].

5. Kalashnikov, D. G. (2003). Teoriya i metodika fitnes-trenirovki: uchebnik personalnogo trenera [Theory and methodology of fitness training: personal coach textbook]. Moskva: Frantera [in Russian].

6. Kim, N. (2006). Fitnes [Fitness]. Moskva: Sovetskij sport [in Russian].

7. Krucevich, T. Yu. (2003). Teoriya i metodika fizichnogo vihovannya: Metodika fizichnogo vihovannya riznih grup naselennya [Theory and Methods of Physical Education: Methodology of the physical education for different population group], (Vol. 2). Kiyiv: Olimp. lit. [in Ukrainian].

8. Kuznecov, A. (2008). Anatomiya fitnesa [Anatomy of fitness]. Moskva: Feniks [in Russian].

9. Nevskij, A. P. (2011). Enciklopediya fitnesa $i$ fizicheskoj kultury [Encyclopedia of fitness and physical culture], (Vols. 2). Moskva: Zebra E [in Russian].

10. Strogan, D. O., Strikalenko, Ye. A., \& Shalar, O. G. (2017). Fizichna pidgotovka zhinok zasobami pruzhinyachih cherevikiv «KANGOO JUMPS» [Physical preparation of women by means of Kangoo Jumps rebound shoes]. Naukovij chasopis Nacionalnogo pedagogichnogo universitetu imeni M. P. Dragomanova Science Chronicle of National Pedagogical Dragomanov University, (86) 17, 331-336 [in Ukrainian].

11. Houli, E. T. (2004). Rukovodstvo instruktora ozdorovitelnogo fitnesa [Wellness Fitness Instructor Guide]. Kiev: Olimp. lit. [in Russian].

12. Shalar, O. G. (2009). Vidpovidalne stavlennya do zdorov'ya yak providna cinnist fizichnogo vihovannya [Responsible health as a leading value in physical education]. Teoriya ta metodika fizichnogo vihovannya Theory and Methods of Physical Education, (5), 26-31 [in Ukrainian].

13. Shalar, O. G., Naumenko, M. V., Strikalenko, E. A. (2010). Formirovanie motivacionno-cennostnogo otnosheniya studentov k sobstvennomu zdorovyu [Formation of motivational-value attitude of students to their own health]. Fizicheskoe vospitanie studentov - Physical education of students, (5), 80-83 [in Russian].

14. Dr. Howie, Wenger. (2005). Army Fitness Manual. Ontario. Command [in English].

15. Schlosberg, S., Neporent, L., \& Drenth, T. S. (2005). Fitness For Dummies, 3rd Edition. Indiana: Wiley Publishing [in English]. 